\title{
STUDI EKSPERIMENTAL PENGARUH EFEKTIFITAS ACWH TERHADAP PANJANG PIPA KAPILER SEBAGAI PENGHANTAR PANAS
}

\author{
Chandra Amirsyah Putra Siregar \\ Fakultas Teknik, Program Studi Teknik Mesin \\ Universitas Muhammadiyah Sumatera Utara \\ Email: chandra@umsu.ac.id
}

\author{
A M Siregar \\ Fakultas Teknik, Program Studi Teknik Mesin \\ Universitas Muhammadiyah Sumatera Utara \\ Email: ahmadmarabdi@umsu.ac.id \\ Affandi \\ Fakultas Teknik, Program Studi Teknik Mesin \\ Universitas Muhammadiyah Sumatera Utara \\ Email: affandi@umsu.ac.id
}

\begin{abstract}
ABSTRAK
ACWH (Air Conditioner Water Heater) merupakan aplikasi rekayasa teknologi AC yang memanfaatkan panas buang dari kompresor. Pemanfaatannya dengan menambahkan alat penukar kalor (APK) yang bertujuan untuk memanaskan air didalam tanki, sehingga dapat memenuhi kebutuhan air panas untuk mandi. Dalam penelitian ini, APK yang digunakan adalah pipa kapiler berbahan tembaga. Tujuan dari penelitian ini adalah untuk mengetahui pengaruh panjang pipa kapiler terhadap kinerja ACWH. Variasi panjang pipa kapiler yakni 8m (1/2 dari ukuran tinggi tanki) dengan 15 lilitan dan pipa dengan panjang 16m dengan 30 lilitan (setinggi tanki). Diameter lilitan sebesar $150 \mathrm{~mm}$. Variable yang akan diuji dan diamati adalah hasil temperatur pemanasan air, temperatur refrigeran keluar kompresor, dan juga temperatur refrigeran masuk kondensor pada waktu 60 menit. Pengujian dilakukan terhadap 3 temperatur evaporator yang berbeda yakni $16^{\circ} \mathrm{C}$, $18^{\circ} \mathrm{C}$, dan $20^{\circ} \mathrm{C}$. Hasil pengujian menunjukkan bahwa alat penukar kalor dengan panjang pipa kapiler $16 \mathrm{~m}$ lebih efektif untuk memanaskan air dibandingkan dengan alat penukar kalor dengan panjang pipa kapiler $8 \mathrm{~m}$. Temperatur air dalam tanki dengan pengujian temperatur evaporator $16^{\circ} \mathrm{C}$ sebesar $53.81^{\circ} \mathrm{C}$ dengan panjang pipa kapiler $16 \mathrm{~m}$. Sedangkan panjang pipa $8 \mathrm{~m}$, diperoleh temperatur air dalam tanki sebesar $53,69^{\circ} \mathrm{C}$. Untuk pengujian dengan temperatur evaporator $18^{\circ} \mathrm{C}$ dan $20{ }^{\circ} \mathrm{C}$ dengan menggunakan panjang pipa kapiler $16 \mathrm{~m}$ hasilnya masing-masing sebesar $51^{\circ} \mathrm{C}$ dan $46.81^{\circ} \mathrm{C}$. Sedangkan menggunakan pipa kapiler $8 \mathrm{~m}$ hasilnya masing-masing sebesar $49.94^{\circ} \mathrm{C}$ dan $49.06^{\circ} \mathrm{C}$.
\end{abstract}

Kata kunci: $A C W H, A P K$, pipa kapiler

\section{ABSTRACT}

ACWH (Air Conditioner Water Heater) is an AC technology engineering application that utilizes exhaust heat from the compressor. Utilization by adding a heat exchanger (APK) which aims to heat the water in the tank, so that it can meet the needs of hot water for bathing. In this research, the APK used is a copper capillary tube. The purpose of this study was to determine the effect of capillary pipe length on ACWH performance. Capillary pipe length variations are $8 m(1 / 2$ of the tank height) with 15 turns and a $16 \mathrm{~m}$ length pipe with 30 turns (as tall as the tank). The diameter of the coil is $150 \mathrm{~mm}$. The variables to be tested and observed are the results of the heating temperature of the water, the temperature of the refrigerant coming out of the compressor, and also the 
temperature of the refrigerant entering the condenser at 1 hour (60 minutes). Tests were carried out on 3 different evaporator temperatures namely $16^{\circ} \mathrm{C}, 18^{\circ} \mathrm{C}$, and $20^{\circ} \mathrm{C}$. The test results show that a heat exchanger with a $16 \mathrm{~m}$ long capillary tube is more effective for heating water than a heat exchanger with a $8 \mathrm{~m}$ long capillary tube. The temperature of the water in the tank by testing the evaporator temperature of $16^{\circ} \mathrm{C}$ is $53.81^{\circ} \mathrm{C}$ with a capillary pipe length of $16 \mathrm{~m}$. While the length of the pipe is $8 \mathrm{~m}$, the water temperature in the tank is $53,69^{\circ} \mathrm{C}$. For testing with $18{ }^{\circ} \mathrm{C}$ and $20^{\circ} \mathrm{C}$ evaporator temperatures using $16 \mathrm{~m}$ capillary pipe the results are $51^{\circ} \mathrm{C}$ and $46.81^{\circ} \mathrm{C}$ respectively. While using $8 m$ capillary pipes the results were $49.94^{\circ} \mathrm{C}$ and $49.06^{\circ} \mathrm{C}$ respectively.

Keywords: ACWH, heat excangher, capilllary pipe

\section{PENDAHULUAN}

Dalam kehidupan modern sekarang ini, mayoritas rumah tangga dan hampir seluruh usaha perhotelan/penginapan, pusat perbelanjaan modern, pusat perkantoran dan tempat pelayanan publik lainnya telah menggunakan mesin pendingin udara (Air Coditioner/AC). Penggunaan AC bertujuan untuk mengkondisikan udara dalam ruangan agar pengguna ruangan merasa nyaman. Selain itu, AC juga diyakini dapat memperbaiki kualitas udara.

Selain AC, penggunaan air panas (water heater) untuk mandi juga sangat berkembang. Pemakaian water heater untuk mandi dapat digunakan baik dalam skala rumah tangga maupun industri. Bahkan hampir seluruh usaha perhotelan telah menyediakan fasilitas air panas untuk mandi. Pada umumnya, air panas untuk mandi dihasilkan dengan menggunakan tungku maupun energi listrik yang membutuhkan biaya/daya yang sangat besar [1]. Salah satu alternatif untuk mengatasi mahalnya biaya tersebut adalah pemanas air tenaga matahari (solar water heater/SWH), namun SWH ini juga masih tergolong mahal dari biaya konstruksi [2]. Namun penerapan SWH sangat didukung oleh letak geografis wilayah Indonesia dengan iklim tropis yang mendapatkan sinar matahari sepanjang tahun [3.4].

Penelitian ini akan mengkaji perekayasaan AC menjadi multi fungsi yakni sebagai pendingin udara sekaligus sebagai pemanas air untuk keperluan mandi. Hal tersebut memungkinkan untuk dilakukan karena pada AC terdapat energi panas yang besar terbuang sia-sia dan potensi energinya sangat besar [5]. Air conditioning water heater (ACWH) adalah pemanas air yang memanfaatkan suhu freon yang sangat tinggi pada saat keluar dari kompresor. Energi panas tersebut merupakan keluaran dari kompresor menuju kondesor. Perekayasaan yang dimaksud adalah dengan penambahan tangki dan heat exchanger yang diletakkan diantara kompresor dan kondesor. Namun yang harus diperhatikan adalah pemilihan jenis APK yang digunakan karena sering kali ditemukan penurunan performa perpindahan panas pada alat penukar kalor $[6,7]$.

Sistem ini bekerja dengan menggunakan alat penukar kalor yang dipasang pada sistem AC sehingga tidak membutuhkan energi tambahan. Terdapat beberapa keuntungan dengan menggunakan sistem Air Conditioner Water Heater (ACWH) yaitu efek pendinginan udara, efek pemanasan air hemat energi dan juga bisa melakukan penghematan baik dalam energi maupun biaya. Dalam hal ini alat penukar kalor yang cocok digunakan untuk memanfaatkan kalor yang terbuang dari kompresor AC adalah penukar panas tipe Shell Helical-Coil dengan bahan dasar tembaga (copper). Hal ini akan mampu mengurungi biaya operasional rumah tangga maupun indutri perhotelan yang memberikan layanan/fasilitas air panas untuk keperluan mandi.

Sistem ini bekeja dengan cara refrigeran masuk ke kompresor melalui pipa tembaga dalam bentuk uap, dalam kompresor refrigeran ditekan sehingga refrigeran keluar berbentuk uap yang sangat panas (vapour superheated) dan bertekanan tinggi. Uap bertekanan dalam siklus Air Conditioning masuk kedalam kondensor, akan tetapi dalam ACWH ini panas refrigeran tidak langsung masuk kondensor melainkan masuk ke wadah yang berisi air untuk memindahkan panas refrigran ke air. Kemudian, refrigeran masuk ke dalam kondensor. Cairan refrigeran masuk ke pipa 
kapiler dan mengalami tenurunan tekanan secara drastis sehingga terjadi flash evaporation seterusnya masuk ke evaporator untuk diubah lagi menjadi uap.

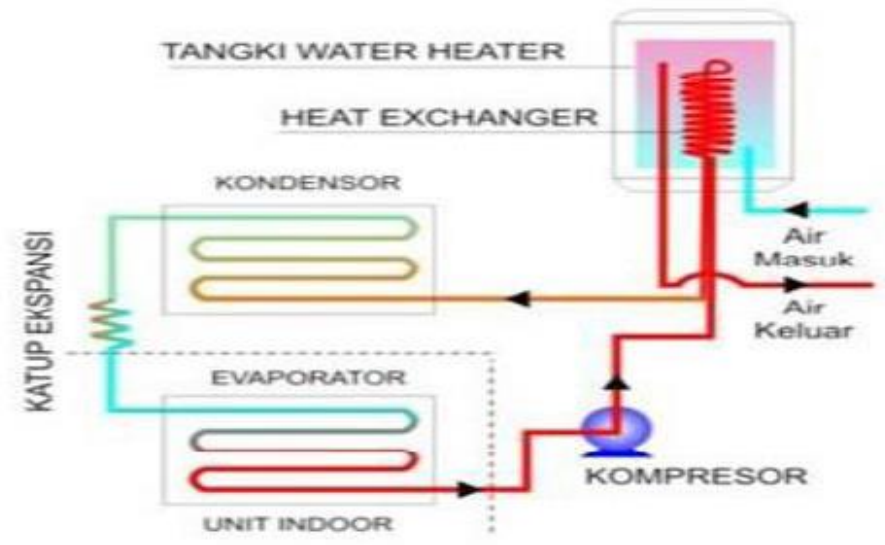

Gambar 1. Skema ACWH [8]

Penelitian yang telah dilakukan yakni ACWH menggunakan APK tipe helix dengan jumlah 3 lilitan dimasukkan dalam tabung dengan dimensi diameter $34 \mathrm{~cm}$, dan tinggi $37 \mathrm{~cm}$ volume air yang bisa ditampung 30liter dengan temperatur dengan suhu air mencapai $60{ }^{\circ} \mathrm{C}$ [9].

\section{METODOLOGI PENELITIAN}

\subsection{Set-up Alat Uji}

Penelitian ini dilakukan secara eksperimental dengan menggunakan AC split dengan daya $1 \mathrm{PK}$, Jenis refrigran yang digunakan adalah R22. Sedangkan tanki air berbahan galvanis setebal $2 \mathrm{~mm}$ dengan dimensi $1200 \mathrm{~mm} \times 2400 \mathrm{~mm}$ berdiameter atas $300 \mathrm{~mm}$ dan diameter bawah $400 \mathrm{~mm}$ dan berkapasitas air 60 liter. Pemilihan galvanis, karena telah banyak digunakan sebagai pipa saluran air, tahan korosi/karat dan pengerjaannya yang lebih mudah dibanding plat stainless. Tangki dilapisi/diisolasi dengan menggunakan insulflex dan plat aluminium dengan tujuan untuk meminimalisir laju perpindahan panas dari dalam tanki ke lingkungan.

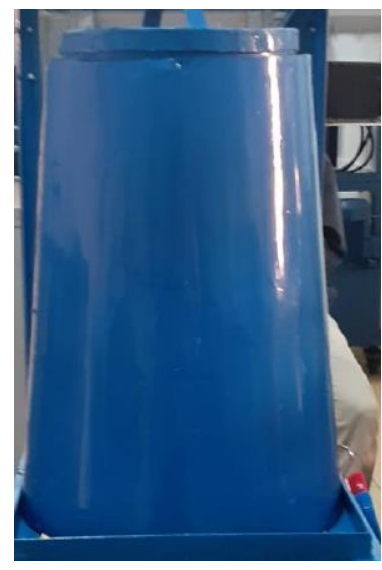

Gambar 2. Tanki Air Pada ACWH 
Pada bagian dalam tanki diberikan pipa kapiler berbahan tembaga sebagai penghantar panas dengan diameter luar $6,35 \mathrm{~mm}$, diameter dalam 5,54mm. Pengujian dilakukan terhadap dua variasi panjang pipa kapiler yakni $8 \mathrm{~m}$ (setengah dari tinggi tanki) dengan 15 lilitan dan 16m (setinggi tanki) dengan 30 lilitan.

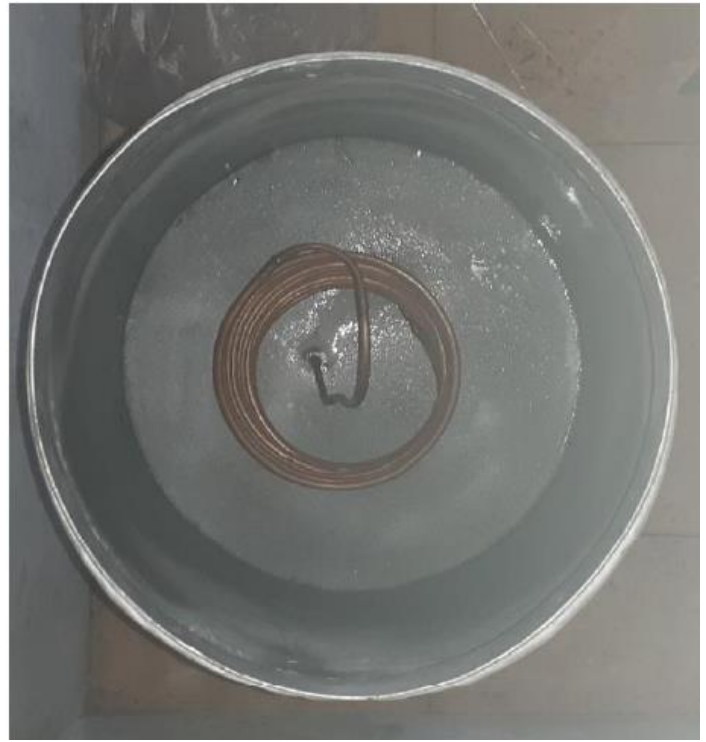

\section{Gambar 3. Posisi Peletakan Helical Coil Pipa Kapiler Sebagai APK Di dalam Tanki}

Untuk mengukur temperatur, diberikan sensor temperatur tipe DS18B20 didalam tanki, keluran kompresor serta masuk kondensor. Ketiga sensor tersebut dihubungkan dengan arduino UNO. Penelitian dilakukan selama 60 menit, dengan 3 variasi temperatur evaporator yakni $16^{\circ} \mathrm{C}$, $18^{\circ} \mathrm{C}$ dan $20^{\circ} \mathrm{C}$. Pencatatan temperatur dilakukan setiap 10 menit sekali. Untuk lebih jelasnya, setup alat uji ditampilkan pada gambar 1 dibawah ini.

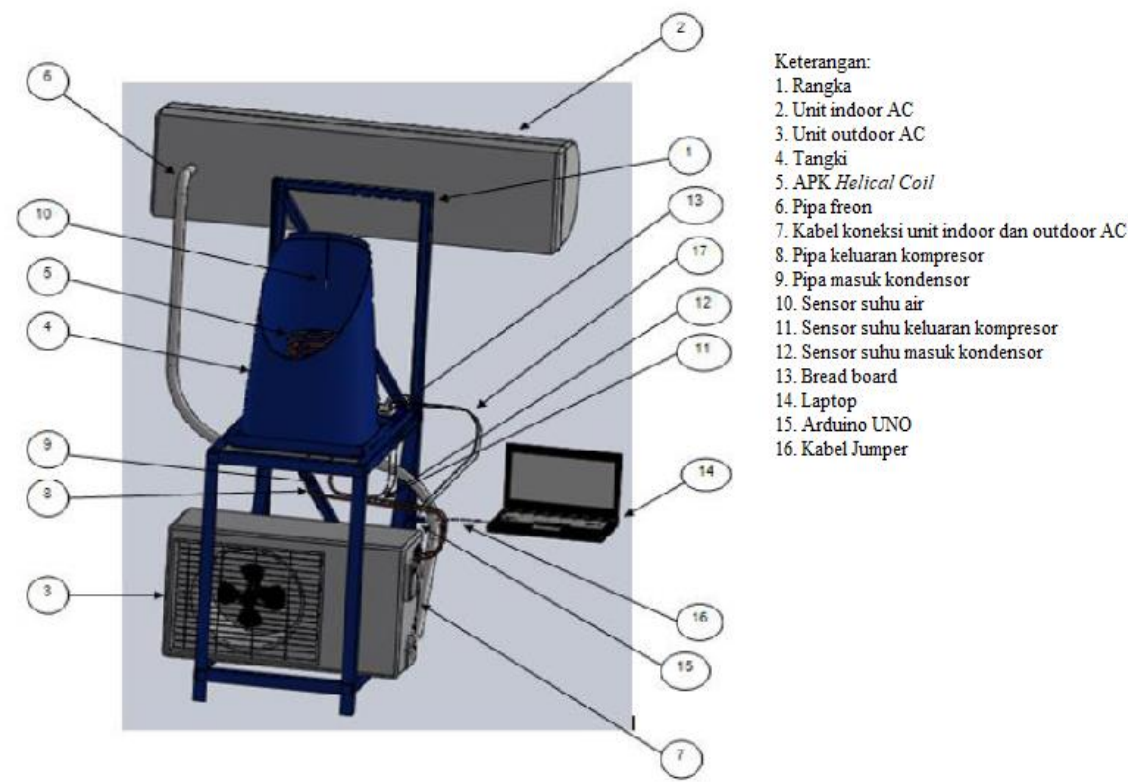




\subsection{Teknik Pengumpulan Data}

Pengumpulan data dan pengambilan data meliputi data temperatur air, temperatur refrigerant masuk kondensor, temperatur keluaran kompresor dan tekanan pada temperatur evaporator AC $16^{\circ} \mathrm{C}, 18^{\circ} \mathrm{C}, 20^{\circ} \mathrm{C}$. Pengambilan data dilakukan selama 60 menit dimulai dari suhu air bertemperatur $29^{\circ} \mathrm{C}$, sampai dengan temperatur air yang diinginkan yaitu $44^{\circ} \mathrm{C}$ (temperatur air untuk mandi), dan sampai temperatur akhir pemanasan air selama 1 jam.

\section{HASIL DAN PEMBAHASAN}

\subsection{Temperatur Air Dalam Tanki}

Dalam penelitian ini dilakukan pengujian terhadap 2 variasi panjang pipa kapiler yakni $8 \mathrm{~m}$ (setengah tinggi tanki air) dan $16 \mathrm{~m}$ (sepenjang tanki air). Pengujian dilakukan terhadap 3 temperatur AC yakni $16^{\circ} \mathrm{C}, 18^{\circ} \mathrm{C}$, dan $20^{\circ} \mathrm{C}$. Hasil pengujian ditampilkan pada tabel 1 dibawah ini.

Tabel 1. Hasil Pengukuran Temperatur Air Dalam Tanki

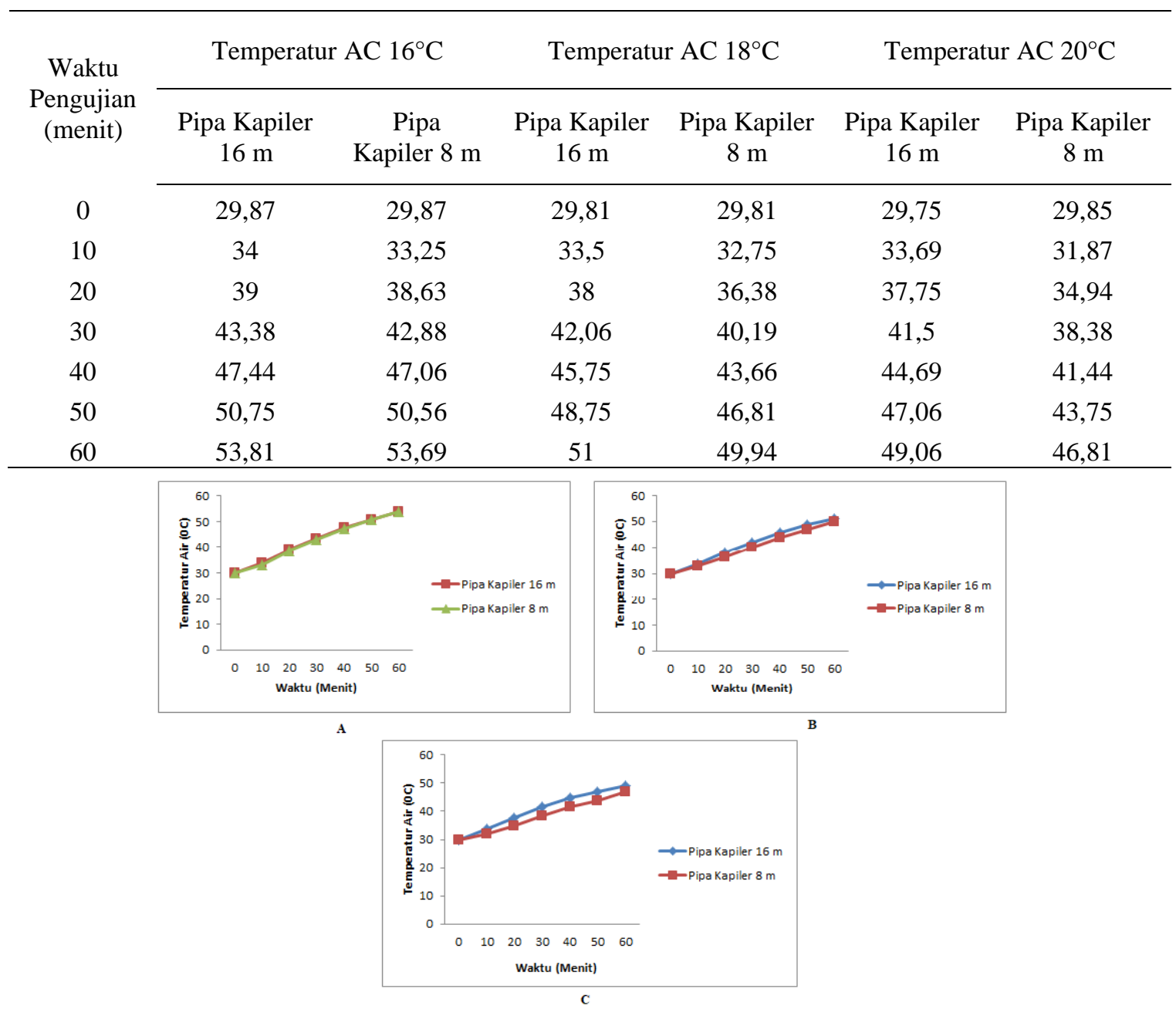

Gambar 5. A. Hasil Pengukuran Temperatur Air Pada Pengujian Temperatur AC $16^{\circ} \mathrm{C}$

B. Hasil Pengukuran Temperatur Air Pada Pengujian Temperatur AC $1^{\circ} \mathrm{C}$

C. Hasil Pengukuran Temperatur Air Pada Pengujian Temperatur AC $20^{\circ} \mathrm{C}$ 
Dari data hasil pengujian diatas, diperoleh bahwa panjang pipa kapiler sangat mempengaruhi kinerja dari ACWH dalam menghasilkan air panas. Semakin panjang pipa kapiler maka semakin baik perpindahan panas ke air. Hal ini terjadi karena laluan uap superheated dari kompresor memiliki jarak yang panjang hingga ke kondensor, sehingga dapat memaksimalkan proses perpindahan panas dari pipa kapiler ke air didalam tanki. Seluruh hasil pengujian memperlihatkan temperatur air tertinggi berada pada panjang pipa kapiler $16 \mathrm{~m}$. Sedangkan untuk mencapai temperatur air $44^{\circ} \mathrm{C}$ (temperatur mandi) hanya membutuhkan waktu 30 menit.

Dalam 60 menit pengujian diperoleh, temperatur air tertinggi dengan panjang pipa kapiler $16 \mathrm{~m}$ untuk masing-masing temperatur pengujian $\mathrm{AC} 16^{\circ} \mathrm{C}, 18^{\circ} \mathrm{C}$ dan $20^{\circ} \mathrm{C}$ sebesar $53,81^{\circ} \mathrm{C}, 51^{\circ} \mathrm{C}$ dan $49,06^{\circ} \mathrm{C}$. Sedangkan untuk pengujian temperatur air pada panjang pipa kapiler $8 \mathrm{~m}$ untuk masingmasing temperatur pengujian AC $16^{\circ} \mathrm{C}, 18^{\circ} \mathrm{C}$ dan $20^{\circ} \mathrm{C}$ sebesar $53,69^{\circ} \mathrm{C}, 49,94^{\circ} \mathrm{C}$ dan $46,81^{\circ} \mathrm{C}$.

\subsection{Temperatur Refrigran Keluar Kompresor} ini.

Hasil pengukuran temperatur keluar komprosor berbeda dengan yang ditampilkan pada tabel 2 dibawah

Tabel 2. Hasil Pengukuran Temperatur Keluar Kompresor

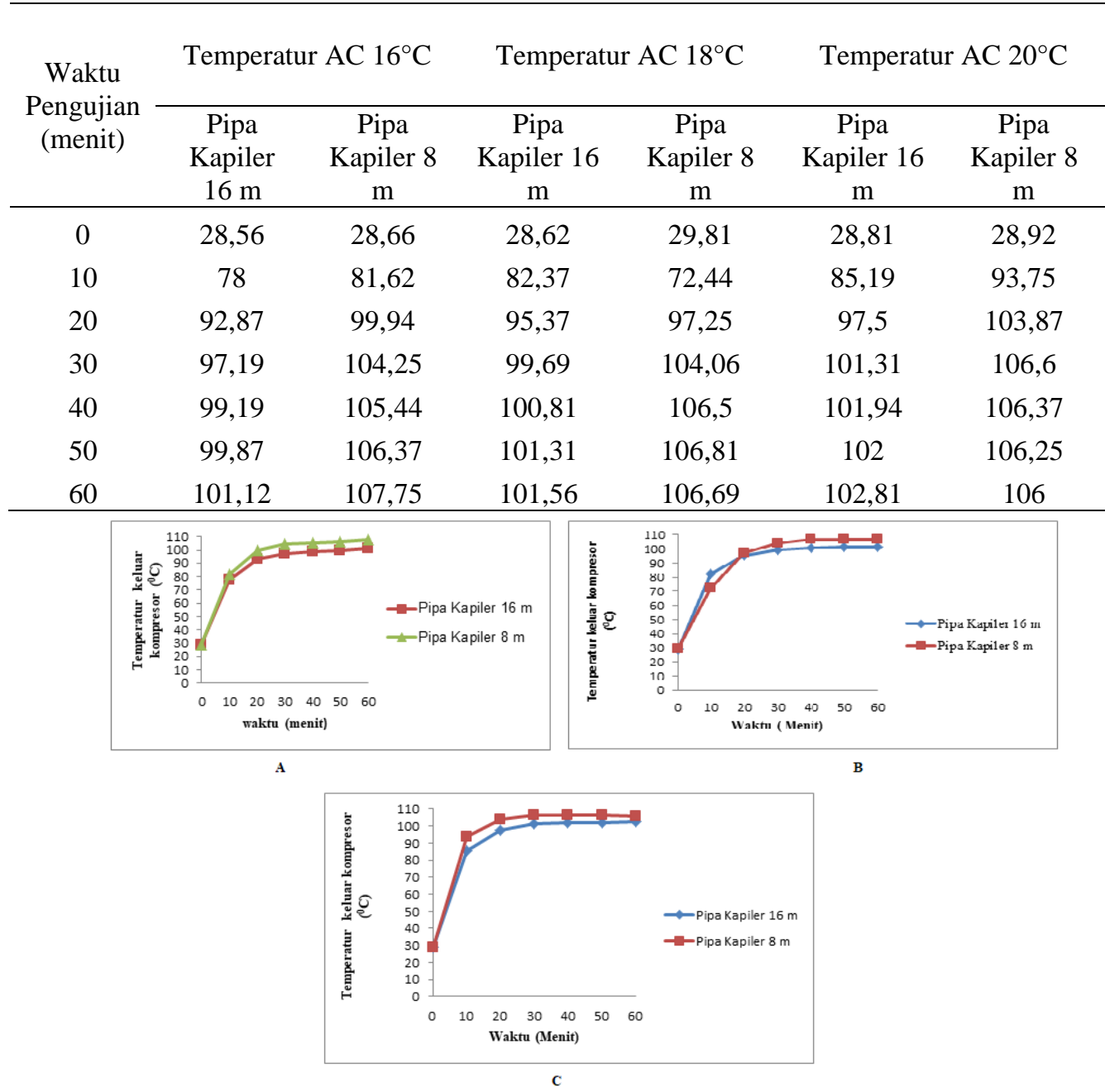


Gambar 6. A. Hasil Pengukuran Temperatur Keluar Kompresor Pada Pengujian Temperatur AC $16^{\circ} \mathrm{C}$

\section{B. Hasil Pengukuran Temperatur Keluar Kompresor Pada Pengujian Temperatur $A C 18^{\circ} \mathrm{C}$ \\ C. Hasil Pengukuran Temperatur Keluar Kompresor Pada Pengujian Temperatur $A C 20^{\circ} \mathrm{C}$}

Dari hasil pengukuran diketahui bahwa untuk temperatur keluar dari kompresor tertinggi berada pada panjang pipa kapiler $8 \mathrm{~m}$. Hal ini kemungkinan disebabkan oleh temperatur refrigran yang ke dalam kondensor lebih tinggi dari dari pipa yang $16 \mathrm{~m}$. Fakta ini didukung oleh penyerapan panas pada air lebih tinggi pada pipa $16 \mathrm{~m}$, sehingga temperature refrigran masuk kondenso lebih rendah, dan dari kondensor ke kompresor juga semakin rendah.

Dalam 60 menit pengujian, diperoleh refrigran keluar kompresor tertinggi dengan panjang pipa kapiler $8 \mathrm{~m}$ untuk masing-masing temperatur pengujian $\mathrm{AC} 16^{\circ} \mathrm{C}, 18^{\circ} \mathrm{C}$ dan $20^{\circ} \mathrm{C}$ sebesar $107,75^{\circ} \mathrm{C}$, $106,69^{\circ} \mathrm{C}$ dan $106^{\circ} \mathrm{C}$. Sedangkan untuk pengujian temperatur refrigran keluar kompresor pada panjang pipa kapiler $16 \mathrm{~m}$ untuk masing-masing temperatur pengujian $\mathrm{AC} 16^{\circ} \mathrm{C}, 18^{\circ} \mathrm{C}$ dan $20^{\circ} \mathrm{C}$ sebesar $101,12^{\circ} \mathrm{C}, 101,56^{\circ} \mathrm{C}$ dan $102,81^{\circ} \mathrm{C}$.

\subsection{Temperatur Refrigran Masuk Kondensor}

Tabel 3. Hasil Pengukuran Temperatur Refrigran Masuk Kondensor

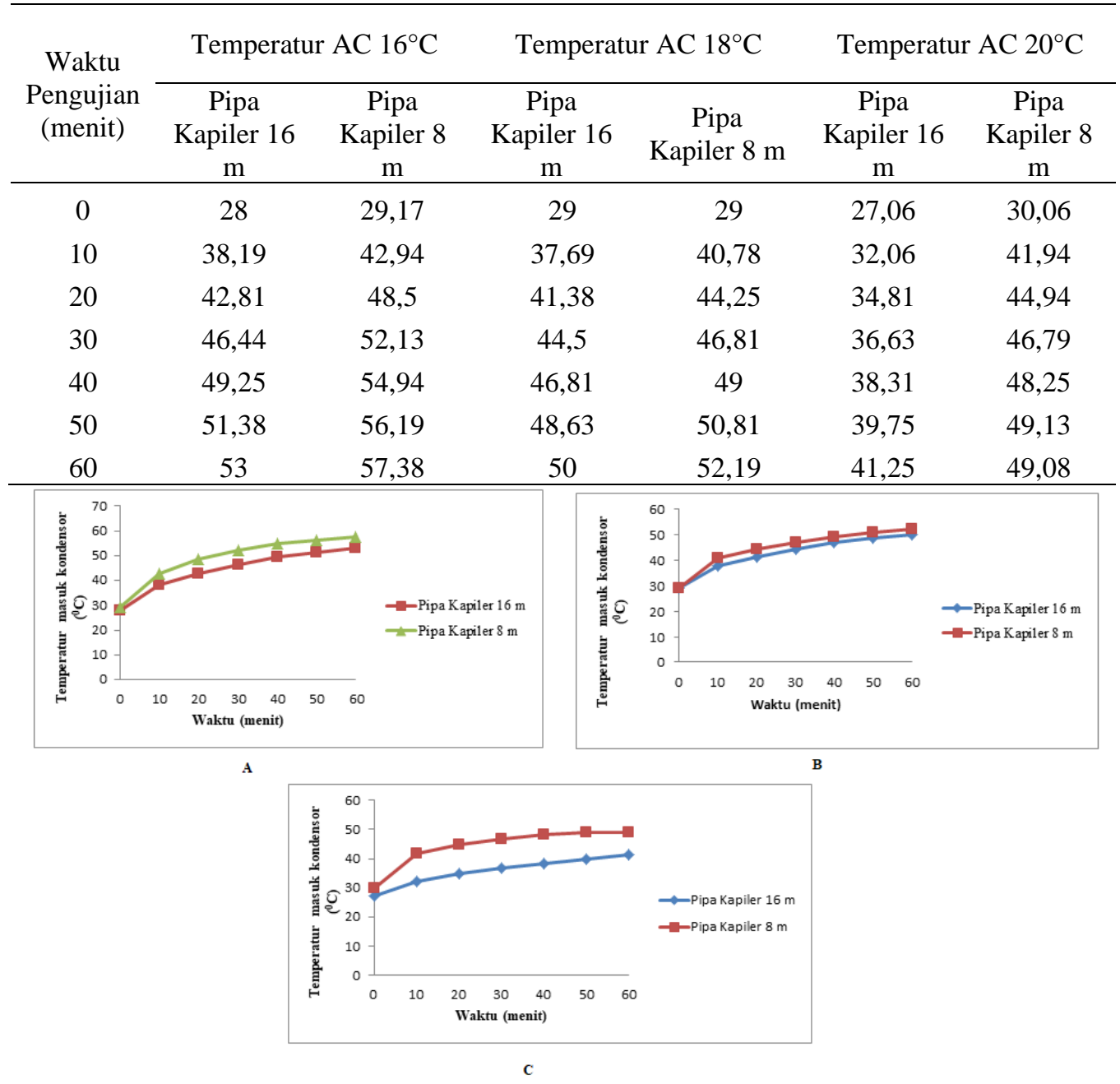




\section{Gambar 7. A. Hasil Pengukuran Temperatur Masuk Kondensor Pada Pengujian Temperatur AC $16^{\circ} \mathrm{C}$ \\ B. Hasil Pengukuran Temperatur Masuk Kondensor Pada Pengujian Temperatur $A C 18^{\circ} \mathrm{C}$ \\ C. Hasil Pengukuran Temperatur Masuk Kondensor Pada Pengujian Temperatur $A C 20^{\circ} \mathrm{C}$}

Temperatur refrigran tertinggi yang masuk kedalam kondensor secara konsisten berada pada panjang pipa kapiler $8 \mathrm{~m}$ dibandingkan dengan panjang pipa kapiler $16 \mathrm{~m}$ yang memiliki temperatur refrigran lebih rendah. Hal ini didukung oleh penyerapan panas pada tanki air lebih maksimal pada panjang pipa kapiler 16m. Dalam 60 menit pengujian, diperoleh refrigran masuk kondensor tertinggi dengan panjang pipa kapiler $8 \mathrm{~m}$ untuk masing-masing temperatur pengujian $\mathrm{AC} 16^{\circ} \mathrm{C}, 18^{\circ} \mathrm{C}$ dan $20^{\circ} \mathrm{C}$ sebesar $57,38^{\circ} \mathrm{C}$, $52,19^{\circ} \mathrm{C}$ dan $49,08^{\circ} \mathrm{C}$. Sedangkan untuk pengujian temperatur refrigran masuk kondensor pada panjang pipa kapiler $16 \mathrm{~m}$ untuk masing-masing temperatur pengujian $\mathrm{AC} 16^{\circ} \mathrm{C}, 18^{\circ} \mathrm{C}$ dan $20^{\circ} \mathrm{C}$ sebesar $53^{\circ} \mathrm{C}, 50^{\circ} \mathrm{C}$ dan $41,25^{\circ} \mathrm{C}$.

\section{KESIMPULAN}

Dari hasil penelitian dan pengujian yang dilakukan dapat ditarik kesimpulan bahwa:

1. Semakin panjang pipa kapiler pada ACWH semakin memaksimalkan penyerapan panas pada air, namun tidak memiliki selisih temperatur yang signifikan.

2. Hasil akhir temperatur pemanasan air menggunakan APK dengan panjang pipa $16 \mathrm{~m}$ pada temperatur evaporator $\mathrm{AC} 16^{\circ} \mathrm{C}$ sebesar $53.81^{\circ} \mathrm{C}$, pada temperatur evaporator $\mathrm{AC} 18^{\circ} \mathrm{C}$ sebesar $51^{\circ} \mathrm{C}$, dan pada temperatur evaporator $\mathrm{AC} 20^{\circ} \mathrm{C}$ sebesar $46.81^{\circ} \mathrm{C}$.

3. Hasil akhir temperatur pemanasan air menggunakan APK dengan panjang pipa $8 \mathrm{~m}$ pada temperatur evaporator $\mathrm{AC} 16^{\circ} \mathrm{C}$ sebesar $53.69^{\circ} \mathrm{C}$, pada temperatur evaporator $\mathrm{AC} 18^{\circ} \mathrm{C}$ sebesar $49.94^{\circ} \mathrm{C}$, dan pada temperatur evaporator $\mathrm{AC} 20^{\circ} \mathrm{C}$ sebesar $49.06^{\circ} \mathrm{C}$.

4. Untuk memanaskan air dalam tanki sampai $44{ }^{\circ} \mathrm{C}$ (temperature air untuk mandi) hanya 30 menit.

\section{UCAPAN TERIMA KASIH}

Pada kesempatan ini, penulis ingin mengucapkan terimakasih kepada Rektor UMSU dan LPPM UMSU yang telah menyetujui pendanaan penelitian ini.

\section{DAFTAR PUSTAKA}

[1]. Bagja, Binar Kusumah. dan Ichsani. Djatmiko. 2016. "Rancang Bangun Dan Studi Eksperimen Alat Penukar Panas Untuk Memanfaatkan Energi Refrigerant Keluar Kompresor Ac Sebagai Pemanas Air Pada St/D=4 Dengan Variasi Volume Air". Jurnal Teknik ITS, Volume 2, Nomor 2, ISSN: 2337-3539.

[2]. Jufrizal., Napitupulu. Farel H., dan Ambarita. Himsar. 2014. "Studi Eksperimental Performansi Solar Water Heater Jenis Kolektor Plat Datar Dengan Penambahan Thermal Energy Storage". Jurnal Ilmiah Teknik Mesin Cylinder, Volume 1. Nomor 2

[3]. Siregar. C.A., Siregar. A.M. dan Lubis Sudirman. 2018. "Pengaruh Jarak Kaca Terhadap Efisiensi Alat Destilasi Air Laut yang Memanfaatkan Energi Matahari di Kota Medan. Journal Of Mechanical Engineering, Manufactures, Materials and Energy. Vol 2. p-ISSN: 2549-6220e-ISSN: 2549-6239 
[4]. Siregar. C.A., dan Siregar. AM. 2019. "Studi Eksperimental Pengaruh Kemiringan Sudut Terhadap Alat Destilasi Air Laut Memanfaatkan Energi Matahari. Jurnal Rekayasa Material, Manufaktur dan Energi, Volume 2 Nomor 1. e-ISSN 2622-7398

[5]. Hermawan. Indra., dan Iswandi. Idris. 2014. "Kajian Potensi Energi Panas Buangan dari Air Conditioner (AC)". Jurnal Teknovasi. Volume 1. Nomor 2. ISSN 2355-701X.

[6]. Umurani. Khairuul. dan M. Muharnif. 2019. Pengaruh Diameter Lubang Pembangkit Vorteks Winglet Melengkung Terhadap Unjuk Kerja Apk Tipe Kompak Studi Eksperimental. Jurnal Rekayasa Material, Manufaktur dan Energi, Volume 2. Nomor 1. e-ISSN 2622-7398

[7]. Siregar. Chandra., dan Irfansyah. 2018. Studi Numerik Unjuk Kerja Penggunaan Winglet Pada Heat Exchanger Tipe Compact. Jurnal Rekayasa Material, Manufaktur dan Energi, Volume 1 Nomor 1. e-ISSN 2622-7398.

[8]. Stoecker, W. F., Jones, J. W., and Hara, S. (1992). Refrigerasi Dan Pengkondisian Udara. Jakarta: Erlangga.

[9]. Hendradinata. Irawan F., dan Kusuma. A. P. (2018) "Rancang Bangun Water Heater Dengan memanfaatkan Panas Air Conditioning" Jurnal PETRA. Volume 5 Nomor 2. ISSN: 2460-8408. 
